\title{
Modern food production-costly or necessary for the consumer?
}

\section{By Jenny Salmon, 8 Cherrydale Road, The Moultway, Camberley, Surrey}

The title of this symposium is 'Nutrition - Value for Money'. Not a particularly obscure title at first sight, but it is worth looking at the concept of value in a little more detail. How do you define value, let alone value for money? And how do you apply general concepts to nutrition? What is the value of a house? Certainly it costs up to $30 \%$ more than it did this time last year, but that does not help us to define its value. It is only worth the money if you really want the house. Someone stuck in the middle of the Sahara desert whose house is in England would probably think it good value to exchange the house for a few pints of water and a certain escape route. The alternative could be death, when the 640000 house will be of little value to him.

Not only is it difficult to be precise about what value means, but the values of societies change with time. A few decades ago a very large number of homes had a fair sprinkling of silver, brass and gold, and just about found room in a corner or the attic for samplers, pieces of lustre ware and pretty grotesque pottery. Today those same samplers, lustre ware vases and egg cups and those same large pots fetch small fortunes in antique sales. It is all attributed to scarcity value. Conversely, the silver to be found in most modern homes, other than the inherited candlesticks and cutlery, is confined to an occasional cigarette box or christening spoon. Gold is probably represented by no more than a wedding ring or two, and brass is found perhaps as a door stop.

Our values have changed. What governs those changes? Certainly scarcity value, supply and demand. That may be the only factor. It must be so in some cases when one considers the price of some postage stamps which are neither pretty nor useful.

Well known examples in the food world are the attitudes to and prices paid for salmon and baked beans over the years. Such fluctuations would not be allowed now that we have the Prices Commission, the Monopolies Commission and probably a few other commissions dabbling in food too. London apprentices rioted in the 183 os because they were offered salmon more than three times a week, and in the early 1900 s baked beans were on sale in Fortnum and Mason at a price equivalent to about $\ell_{1} \cdot 50 /$ lb today. Now, images are completely reversed. Not many of us would have the nerve to invite friends, or even duty guests we can't stand, to a meal and give them baked beans on toast, but if we really wish to impress them we might 'push the boat out' and offer salmon at $f_{4} .00$ a pound.

Another determinant of value for money, or the worth of a particular item at any time, is fashion-equally applicable to houses, food and cars, although the prime example is found in the clothing industry. There may not be extremes in prices here, but certainly mass produced items of plastic jewellery or cheesecloth blouses 
are sold at higher prices than they need be, simply because young people are willing to pay the asking price. We are talking about things which are, by no stretch of the imagination, essential to life and there is no reason why manufacturers should not make good profits if they are far-sighted enough to judge the market and are willing to take the capital risk inevitably involved in an entrepreneurial venture. It is often said, usually by the older generation, that we have lost our sense of value, that in a commercial world we value nothing that we cannot buy, use and throw away. We set little store by the beauty of scenery or moral values. Is there any trust in that in a general sense, and have we no sense of values about the food we eat?

The issue could be debated for ever, but it is probably not true that society has lost its sense of values. They may have changed in a way the older generation finds unacceptable, but they are still there. In the quarter century up to 1975 there was massive increase in prosperity. People came to expect more, to want more material goods. At least one sociologist believes the British sense of values has gone through a metamorphosis and that what is now emerging is a sense of 'real' values not just materialistic value. Thus value and value for money are not easy terms to define and we cannot say that what is good value for one person is necessarily so for everyone. At its most fundamental the value of any article or service is the price people are willing to pay. Why else would house prices have rocketed? The specific issue of nutritional value for money is no easier to define. Maybe if one can measure the amount of any given nutrient and you know the cost/unit weight of a selection of foods in which that nutrient is found, then it is easy to calculate the best nutritional value for money. It is a little more difficult, but not beyond the wit of the statistician, to integrate the unit costs of a series of nutrients in such a way that we arrive at an over-all nutritional value for money index for every food. However, the social nutritionists must have influenced us because everyone will react with indignation and protest that nutrition is 'more than nutrients'. People eat food not nutrients. A very cheap food with all the protein, vitamins and minerals in the correct proportions is very poor value for money if no-one will eat it.

\section{Nutritional value for money}

Nutritional value for money is no easier to define than the value of anything else. In the years of galloping inflation, now mercifully reduced to a gentle canter, one might have expected people to look more and more to less expensive versions of familiar foods, to sacrifice a little quality to save money. That happened to only a limited extent. There is a tendency among the British to refuse to accept second best. With some exceptions if people can't afford the best piece of beef they will buy the best chicken in preference to cheaper cuts of beef. This tendency isn't as strong as it once was, but it is still there. This reinforces the influence of habit in deciding which foods we choose. At any time, price, nutritional value and whim may play their parts, but to quote John McKenzie in People and Food Tomorrow-'The very fact that last year or last week the budget was divided in 
this way; that the main meal of the week normally comprises these items; that breakfast always includes cereal and the main meal of the day potato, is mostly strong enough to ensure that similar demand is made the coming week'.

When money becomes scarce people want to be sure that what they do spend on food, clothes or furniture is money well spent, that the purchases will show good taste, give good service or good wear. There is therefore a tendency to avoid buying inferior products by choosing branded goods and the brands which became familiar when times were not so hard. Research has shown that young women, under 35 , tend not to be as thrifty as their parents. They are more likely to live for today and to make value judgements which are not so dependent on money. The reliance on branded goods is precisely what happened during the 1976-1977 period. Until 1976 growth in distributor's own brands in food had been steady. But as inflation increased the growth ceased and branded foods came back into their own. Every consumer makes some kind of value judgement occasionally. The value of food is judged by its ability to fill the family, its taste, keeping qualities and price. The one feature that is not in the list is nutrient content. The refusal to change and to hang on to what is familiar and of proven value is more evident in food than any other aspect of life. At the extreme, it is reputed that some people starve rather than eat food which is unfamiliar. Britons are not very different; one can present them with all kinds of information about relative nutritional values for money but there is no guarantee it will have any influence on purchasing behaviour.

The problem may be that people don't know how to cook the cheaper cuts of meat, but every woman's magazine in the country has been telling the housewife how to make delicious dishes with scrag end, offal and pulses. She may even read them, but many housewives are unlikely to actually put the advice into practice. Part of the reason, of course, is lack of time, or more accurately, an unwillingness to spend time in the kitchen. Hence the continued expansion of the prepared food market.

Cookery writers and teachers, the Women's Institute and the Friends of The Earth implore women to save money and the environment by turning the clock back a few decades and doing more of the basics in cooking for themselves. No matter how much these economies are advanced they will make very little headway as long as the proportion of women who seek outside employment continues to increase (in 1974, $49 \%$ of women in the UK were in some kind of employment) and as long as women prefer leisure activities to peeling vegetables.

Smaller families, having children later in life than was previously the norm, and sending children to nursery school at the age of three or four have all contributed to the tendency for more women to work, not always because they have to make ends meet, but because they want to. Even women who do have time to spend scraping potatoes, shredding oranges for marmalade or whipping up homemade mayonnaise may begrudge the time they spend in the kitchen and opt instead for leisure activities and the use of prepared food. Sunday is the one day the working wife has to herself and you might expect that she would devote time to basic home 
cooking to prepare the Sunday lunch. In fact, this is the last thing she thinks of doing! Only $56 \%$ of housewives now consider that Sunday lunch is the most important meal of the week, and for young couples without children the proportion is much smaller.

The statements that prepared foods are expensive and do not represent value for money may, in terms of nutrients/unit weight be partly true, but for a large number of people who simply do not want to spend time preparing fresh foods they represent excellent value for money. Consumers expect to pay for convenience, it is a very few vocal members of various groups who try to persuade people that prepared foods are too expensive. This does not encourage food suppliers to sell their wares. Of course, the foods are on sale, but that is not the same thing.

\section{Advertising}

Lord Thompson, in his book Life After Sixty, said, 'I still can't get over the antipathy I find in Britain to the art and skill of salesmanship. Napoleon used to call the English a nation of shopkeepers, but that must have altered a long time ago. Although nowadays there are some firms which are noticeable exceptions, the general run of British businessmen still instinctively look down on hard selling. The almost universal attitude is "I make good stuff and the public don't need to be told"'.

The fallacy of that argument is obvious. If the companies with good products to sell do not advertise their foods, the companies with the not so good products certainly will, and a great disservice to the consumer may result. Instead of refraining, the reputable food producer, ought to advertise more not only by taking more space on television, road hoardings and in the press, but in other ways. Advertising has its uses, even to reputable nutritionists but it must be the most maligned form of communicating to the consumer. The principal function of advertising is to increase sales and to get foods into retail stores. Without advertising the number of salesmen needed would increase dramatically, sales would drop and prices would probably rise.

Surprisingly only a small proportion of all the foods on sale are advertised. It is not unusual for a company producing a hundred or so foods to spend half its advertising budget on the three or four leading lines. If one asked housewives to estimate the amount of money spent on advertising, one would probably get a large range of answers. Almost certainly they would all be too high. In fact, measured against retail selling price, the average expenditure for the food industry is 3 or $4 \%$. It is higher for some foods and may be as high as $10 \%$, but the average of $4 \%$ must be lower than many people imagine.

The purpose of advertising to the consumers is, of course, to persuade them to buy particular brands or foods. Its proponents say it can do no more than present products or services to people and give them a small amount of information. The opponents hold the view that advertising is unfair, that it persuades people to buy foods they do not want and much less need. On reflection, this could only be true if consumers had no choice, were forced to buy and had no powers of discrimination. 
There would be no need to advertise at all! Food advertising, at its most brilliant, will persuade a housewife to try a new product or will tempt her away from one brand to another, but no advertising in the world will make the housewife buy the product a second time if she doesn't like the taste the first time or she thinks it represents poor value for money. Contrary to the idea perpetuated by some people, the British housewife is not mindless and undiscriminating.

\section{Nutrition education}

There is no justification for dishonesty in advertising, be it explicit or implicit and if people buy the wrong balance of foods, and they could benefit nutritionally or financially by choosing differently, then the answer is education. Without resorting to a dictatorship the most useful action is to give people the best information available in a way they can understand and leave them to make their own decisions about what they actually buy and eat. The trouble with nutrition education to date, apart from the fact that the advice seems to be changing daily, is that it is almost always presented in a very boring way. There are even differences in the kind of information which is acceptable to different sections of the community.

The majority of diseases that confront us now are the degenerative disorders of old age. Yet we are trying to persuade people between the ages of 10 to 30 -yearsold to change their eating habits to try to make them live a bit longer. To many people, life extends as far as the end of the week when they receive their pay packet, pay the rent, and stop work for two days. They tend not to have mortgages, to contribute to life insurance schemes or to think very far ahead. To other people the concept of old age does have some meaning. Money is committed to insurance and to mortgages, and salary is paid monthly. It is almost a waste of time telling the former group that if they eat differently from the age of twenty they will live longer. It isn't exactly a thrilling subject for the others but if the message is worth getting across it is worth spending some time thinking how best to do it.

Nutrition education might be better termed food education, since we are trying to effect a change in food choice. There is a case for using the same techniques as the advertising people, together with any other appropriate communications medium. One thing is certain, the classical approach of talking about nutrients has not made great inroads into effective change in most people's lives. Constant repetition of the same message is necessary to get people to change their food habits and the revision of nutritional concepts has resulted in people losing faith in professional opinions.

A great deal of the nutrition education outside schools, and some of it inside has been assisted by the food industry. Books, leaflets and charts have been widely used, and a great deal of care goes into their preparation.

It is only recently that real interest in health and nutrition has become apparent. Slimming led the way, and for some time that was the extent of nutrition for many people. Now the broader concepts of healthy eating and exercise are being 
accepted. Although the terminology of nutritionists is still very confusing to many people, the recognition of words like cholesterol, polyunsaturated fats and dietaryfibre has increased dramatically over the last five years. Research has shown that a significant number of people are trying to eat more wholemeal bread, less fat and less sugar. Whether that is actually the case, only food consumption statistics will show.

For the foreseeable future, it seems that if we want people to change the nutritional composition of their diets, the food industry will have to make the 'promoted' foods more attractive and reasonably priced so that people simply want to eat them. 